\title{
Determinants of Commercial Bank Growth Among Listed Banks in Nairobi Securities Exchange
}

\author{
John Kimaiyo Cherutich \\ Masters Student, Jomo Kenyatta University of Agriculture and Technology, Kenya \\ Dr.Willy Muturi \\ Jomo Kenyatta University of Agriculture and Technology, Kenya \\ Dr. Wallace Atambo \\ Jomo Kenyatta University of Agriculture and Technology, Kenya
}

\begin{abstract}
The main purpose of the research was to establish determinants of commercial bank growth. The specific objectives of the study was to; determine the effect of default rate on loans on growth of commercial banks, determine the effect of level of interest income on growth of commercial banks and to establish the effect of forex transaction volume on growth of commercial banks listed in Nairobi Securities Exchange. The study was guided by the interest rate theory, international fisher effect theory and time preference theory. Using multiple regression analysis, we found support for the proposition that loan default rate, interest rate and forex transaction had a significant effect on growth of commercial banks.
\end{abstract}

Keywords: Growth of commercial bank, default rate on loans, interest income and forex transaction volume DOI: $10.7176 / \mathrm{DCS} / 9-1-06$

\subsection{Introduction}

Growth is organizational outcome that resulting from the combination of firm-specific resources, capabilities and routines (Nelson and Winter, 1982). A firm's growth opportunities are highly related to its current organizational production activities (Coad, 2009). Commercial bank growth is uncertain because of environmental conditions such as competition and market dynamics. Determinants of an organization or firm is classified into three dimensions: individual, organizational and environmental determinants (Baum et al., 2001). The fundamental tenet of investment theory and the traditional view of monetary policy transmission is that a rise in interest rates has a negative effect on firm capital expenditures which will eventually effect its growth. Banks today are the largest financial institutions around the world with branches and subsidiaries throughout everyone's life. However, commercial banks are facing challenges in terms of maximizing shareholder wealth due to the volatility in interest rate dynamics.

Interest rate volatility influences loan default, interest income and forex transaction volume which in the long run affects the level of revenue and growth of commercial banks. High interest rates may lead to high cost of credit thus denying business enterprises the opportunity to venture into projects. The variability of interest rates has a significant relationship with inflation and prices of various products within any given economy. When interest rates are low most business establishments are able to access cheap credit from banks or through open market operations in order to finance their projects. This is likely to impact on the revenue and profitability of commercial banks. On the other hand, high interest rates may lead to high cost of credit thus denying business enterprises the opportunity to venture into projects that require employment of enormous financial resources (Beck and Hesse 2006). Interest rate is a key building block in firm's capital cost, which, combined with the resulting stream of expected cash flows, constitute the primary determinants of whether and how much a firm will invest (Caballero, 1999).

Efficient financial systems has been associated to accelerate long-run economic growth (Levine and Zervos, 1998; Rajan and Zingales, 1998). The World Bank and IMF have strongly urged countries to adopt appropriate regulatory and supervisory measures in their financial systems so as to promote institutional and economic growth (Barth, Caprio and Levine, 2001). In Kenya, there is evidence of high interest volatility that is blamed on poor macroeconomic policies which include excessive government spending, high inflation, and overvalued exchange rates. Distortional macroeconomic policies are at times intentional since politicians believe that high interest, inflation and overvalued exchange rates are good for economic performance.

However firms/organizations are face challenges when macro-economic variables are affected by interest rate volatility will in the long run affect commercial banks performance and eventually growth. According to Williamson, (1990) normally when macroeconomics policy are formulated banks performance is usually not considered. There is little research that focuses on the effect of interest rate volatility on commercial bank growth. Specifically studies (Pierrre \& Christopher, 2009: Olweny, 2011; and Archer, 1995) have looked at the relationship between interest rate and bank performance but not on commercial bank growth. Interest rate 
volatility may affect the price of credit and this is likely to affect the financial performance of these companies. This study sought to bridge this gap by establishing the effect long term effect of interest rate volatility on loans, interest income and forex transactions on commercial bank growth.

\subsection{Theory and hypotheses development \\ 2.1 Empirical Review}

Garner (1986) carried out a study to establish whether interest rate volatility can affect demand for money. The aim of the study was to confirm whether high interest rate volatility is the main reason behind higher average interest rates that discourage business investment decisions and consumer purchases of durable goods. The study also sought to establish whether high interest rate volatility may depress capital spending through increment of the risks that are associated with investment decisions. According to Garner (1986) interest rate volatility has no effect on demand for money and organizations will borrow when they want to meet their capital expenditures despite of interest rate volatility. According to Vaish (2000) the demand for capital consists of the demand for productive and consumptive purpose. Capital is demanded by the investors because it is productive. But the productivity of capital is subject to the law of variable proportions (additional units of capital are not productive as their earlier units).

However, the supply of capital according to Jhingan (2001) depends upon savings rather upon the will to save and the power to save of the community. Some people save irrespective of the rate. They would continue to save even if the rate of interest were zero. There are others who save because the current rate of interest induces them to save and reduce when the rates are low. The higher the rate of interest, the larger the community savings and more will be the supply of funds. The supply curve of capital or the savings curve moves upward to the right. Based on the findings of Ali, Akhtar, and Ahmed (2011) commercial banks should consider the effects of organization policy on interest rate volatility since it may possibly affect real economic variables such as business investment spending and bond prices. Piere and Leslaw (2001) also conducted a study on the volatility clustering in real interest rates among 10 countries. The main aim of the study being the establishment of how real interest rates are influenced by the introduction of inflation targets. The study findings reveled that introduction of inflation targets reduces the volatility of real borrowing or lending rates, even when we control for the stage of the business cycle.

However the conditional covariance depends on the level of the short rate which has implications for hedging equity returns against short term interest rate movements. Interest rate volatility has also been linked to mortgage financing sector. According Duarte (2006) carried out a study to find out the empirical evidence and theoretical implications of the causal effect of mortgage re-financing on interest-rate volatility. An empirical examination by the study suggests that the inclusion of information about mortgage backed securities considerably improves model performance in pricing interest-rate options and in forecasting future interest-rate volatility. The empirical findings from the results showed consistent with the hypothesis that mortgage backed securities hedging affects both the interest-rate volatility implied by options and the actual interest-rate volatility. The results also indicate that the inclusion of information about the mortgage backed securities universe may result in models that better describe the price of fixed-income securities.

According to Maana et al., (2010) carried out a study on modeling the volatility of exchange rates in the Kenyan market. The considered the application of the generalized autoregressive conditional heteroscedasticity process in the estimation of volatility in the Kenyan exchange rates. The findings from the study confirm that exploratory analysis showed that the exchange rates are leptokurtic and slightly positively skewed. This implies that the exchange rate depreciation was preferred during the period, probably to ensure that Kenya's exports remained competitive. According to Kim and Stock (2011) if interest rate volatility increase it has an effect on firm's debt volatility, the firm is more likely to reach a critical value for default, which will result to a higher yield spread. The study established that interest rate volatility is positively related to yield spreads on noncallable bonds. The main aim of the study was to determine whether the positive effect of interest rate volatility on yield spreads is stronger or weaker for callable bonds than for non-callable bonds. Olweny (2011) also conducted a study on modeling volatility of short-term interest rates in Kenya. The main purpose of the study was to establish the link between the level of interest and the volatility of interest rates in Kenya using the Treasury bill rates.

\subsection{Determinants of Commercial Bank Growth}

\subsubsection{Loan Default and Growth of Commercial Banks}

Loan default can be defined as the inability of a borrower to fulfil his or her loan obligation as at when due (Balogun and Alimi, 1988). High default rates in commercial banks should be of major concern to policy makers in developing countries, because of its unintended negative impacts on commercial bank financing. Von-Pischke (1980) states that some of the impacts associated with default include: the inability to recycle funds to other borrowers; unwillingness of other financial intermediaries to serve the needs of small borrowers; and the creation 


\section{of distrust.}

As noted by Baku and Smith (1998), the costs of loan delinquencies would be felt by both the lenders and the borrowers. The lender has costs in delinquency situations, including lost interest, opportunity cost of principal, legal fees and related costs. For the borrower, the decision to default is a trade-off between the penalties in lost reputation from default versus the opportunity cost of forgoing investments due to working out the current loan. Evidence suggests that collateral values and recovery rates on corporate defaults can be volatile and, moreover, that they tend to go down just when the number of defaults goes up in economic downturns (Gambacorta, 2004). This link between recovery rates and default rates has traditionally been neglected by credit risk models, as most of them focused on default risk and adopted static loss assumptions, treating the recovery rate either as a constant parameter or as a stochastic variable independent from the probability of default.

Loan default is the failure to promptly pay interest or principal when due. Default occurs when a debtor is unable to meet the legal obligation of debt repayment. Borrowers may default when they are unable to make the required payment or are unwilling to honor the debt. The failure to perform on a futures contract as required by an exchange. Defaulting on a debt obligation can place a company or individual in financial trouble. Loan default level can be measured as the ratio of Non-performing loans to total loans ratio (NPLR) which will be the indicator of loan default rate level. An increase in provision for loan losses implies a higher cost of bad debt write offs. Given the risk-averse behavior, banks facing higher credit risk are likely to pass the risk premium to the borrowers, leading to higher spreads (Gambacorta, 2004). Hence the higher the risk, the higher the pricing of loans and advances to compensate for likely loss.

The traditional focus on default analysis has been partly reversed by the recent significant increase in the number of studies dedicated to the subject of recovery rate estimation and the relationship between default and recovery rates. This link between recovery rates and default rates has traditionally been neglected by credit risk models, as most of them focused on default risk and adopted static loss assumptions, treating the recovery rate either as a constant parameter or as a stochastic variable independent from the probability of default. This traditional focus on default analysis has been partly reversed by the recent significant increase in the number of studies dedicated to the subject of recovery rate estimation and the relationship between default and recovery rates. This paper presents a detailed review of the way credit risk models, developed during the last thirty years, treat the recovery rate and, more specifically, its relationship with the probability of default of an obligor.

Hoque and Hossain (2008) investigated the association of loan defaults rate and higher interest rates and found out that interest rate policy should be stabilized to enhance the repayment capacity of borrowers for lowering the default rates. They found that loan "defaults were highly correlated with higher interest rates which increase the debt burden on borrowers and leads to defaults resulting in capital erosion of banks. Research conducted by Asari, et al. (2011) was also on the same lines and concluded that Non-performing loans and interest rates have significant relations. Their study suggested that increase in the Non-performing loans result in deterioration of bank assets and subsequently capital erosion. According to Dash and Kabra (2010), commercial banks with aggressive lending strategies charging relatively higher rents on lending incur greater Nonperforming loans. Study conducted by Kaplin, et al. (2009), empirically supported negative correlation between interest rate volatility and loan defaults using data of large non-financial US firms for the period 1982-2008.

\subsubsection{Level of Interest Income and Growth of Commercial Banks}

The structural changes in a bank's net interest income which is equivalent to net interest margin always have a huge impact on profitability of commercial banks which is likely to lead to changes in the bank's behavior, for instance in its risk taking. The bank's net interest margin results from a mix of interest-bearing products and as the rates of these products are differently linked to (market) interest rates, the structural impact of changes in the (market) interest rate level on this margin is not obvious. According to Dash and Kabra (2010) all the interestbearing assets and liabilities are directly linked to market rates and if there is no gap between the volumes of interest-bearing assets and liabilities, then, in the long run, a bank's net interest margin will not be affected by (parallel) shifts in the interest rate level.

In the short run, the net interest margin may fluctuate as a consequence of shifts in the interest rate level, even if all assets and liabilities are completely linked to market rates. To illustrate this point, we take the example of a bank that recursively invests in long-term government bonds and that finances this investment by issuing short-term bonds. In the short run, its net interest income fluctuates when there is a parallel shift in the term structure of interest rates. This is so, because the assets have a longer maturity than the liabilities, with a given time span, a portion of the assets is adjusted to the new interest rates which is smaller than the portion of liabilities that is adjusted. In the long run, however, the net interest margin of this bank will be unaffected by parallel shifts in the term structure, because all the assets and all the liabilities will then be adjusted to the new interest rates(Baum, Mustafa, and Neslihan, 2009).

Memmel (2011) empirically analyzes the short-term effects of changes in the term structure on the banks' net interest margin. Constructing a passive trading strategy in risk-free government bonds and scaling its return with a bank's exposure to interest rate risk, he finds that this scaled return explains a significant part of the 
changes in the banks' net interest margins. However, the long-term effects of parallel shifts in the term structure are zero by construction, because he implicitly assumes that all interest-bearing positions in the banks' balance sheet are completely linked to market interest rates. The bank net interest margin will affect present book value of the bank. Since increase in the interest rate level leads to a temporary decline in the banks' net interest rate margins (Memmel, 2011, 2014).

Alessandri and Nelson (2014) provide a theoretical model with a positive relationship between the interest rate level, the banks' net interest margin and bank growth. The bank's mark-up on loans is a constant multiple of the market interest rate which affect bank growth (Memmel, 2011). The net interest margin of bank increases with the level of interest rates. However the theoretical model of Ariccia et al. (2014), an increase in the interest rates leads to a decline in the net interest margin, which then has an impact on the banks' risk taking and hence low profit and decline in commercial bank growth.

\subsubsection{Effects of Forex Transaction Volume on the Growth of Commercial Banks}

It is widely believed that changes in exchange rates have important implications for financial decision-making, profitability and growth of firms. At the macro level, there is evidence that the creation of such currency unions results in a dramatic increase in bilateral trade (Frankel and Rose, 2002). The existing literature on the relationship between international stock prices (at the industry or firm level) and exchange rates finds only weak evidence of systematic exchange rate exposure (Doidge et al., 2003; Griffin and Stulz, 2001). This is an empirical evidence of US firm hence need to establish the effect in developing countries such as Kenya. According to Hudon et.al. (2006) financial institutions are still exhibit better management ratings. According Omagwa (2005) most banks consider credit/default risk to be the most critical of all the financial risks though empirical evidence shows that foreign exchange risk is the most critical risk for most firms.

Since most banks, foreign exchange risk management systems were governed by guidelines set by at head office (highly centralized foreign exchange risk management systems). Most banks, regardless of their size, extensively utilized most of conventional hedging instruments. Transaction exposure was rated as most critical. Transaction exposure was through buying and selling foreign currencies, cross currency dealings and investing and financing in foreign currencies. The US dollar, sterling pound and Euro were currencies that were greatly traded and thus had the greatest contribution to foreign exchange risk. The foreign exchange risk management practices they used to mitigate foreign exchange risk were forward contracts (most frequently used), money market hedge, currency swap, and currency option Ubindi (2006). According to Kipchirchir (2011) there is a significant relationship between financial performance for multinational corporations and exchange rate volatility in Kenya. This was attributed to the difference between trading currency and financial reporting currency.

\subsection{Research Gap}

Volatility of interest rates is mainly caused by the monetary policy changes that are applicable by the central bank of any government. The volatility of interest rates may have an impact on the entire economy and even greater impact to some other sectors of the economy. Volatility of interest rates for instance does affect capital investments and stability of prices in any given economy (Henry, 2005). The empirical evidence available reveals that short term interest rates in any country have a positive correlation with the volatility of interest rates. This means that when the short term interest rates are high, there are high chances of having high interest rate volatility which will affect cash flows and eventual growth of commercial banks. Theoretical investors pay interest because they have engaged capital in productive activities, therefore the study will seek to establish the impact of interest rate volatility affect growth of commercial banks in Kenya putting in consideration that studies that have establish the effect of interest rate volatility on growth of commercial banks have establish contradicting results.

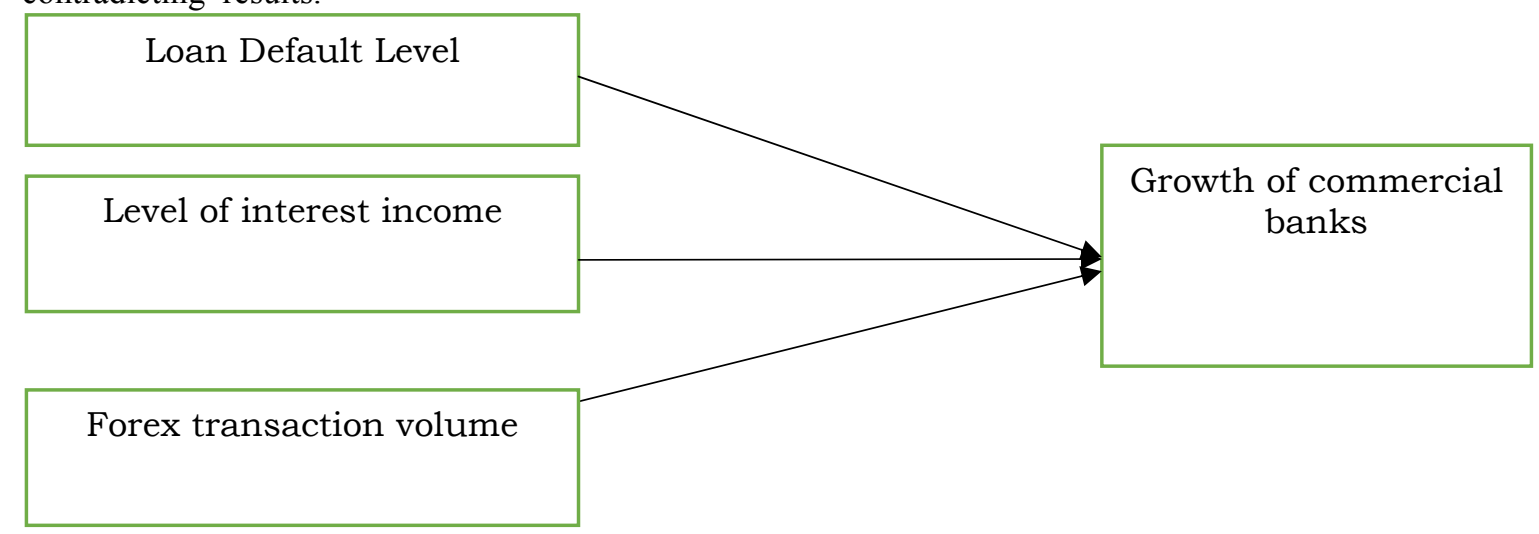

Figure 1. The study model. (Study survey 2016) 


\subsection{DATA AND METHODOLOGY}

\subsection{Research Design}

The study used a descriptive design since we focused on getting inferences from the findings on the effect of default loans rate, interest income and the effect of forex transaction volume on growth of commercial banks listed in Nairobi Securities Exchange, Kenya.

\subsection{Population and Sample Size}

The population of the study consisted of the study consisted of 10 commercial banks listed in Nairobi Securities Exchange, that were listed before 2010. The study utilized a data set of between 2011 and 2014 (Central Bank Directory, 2015). According to the central bank of Kenya directory (2015), there are six banks that have been listed in Nairobi stock exchange and categorized as large commercial banks. The six commercial banks selected purposively formed the sample size of the study.

\section{Table 1 Target Population}

\begin{tabular}{clll}
\hline Bank Name & Size & Year of Establishment \\
\hline 1. & Diamond trust bank & Medium & 1946 \\
2. & CFC Stanbic holding Ltd & Large & 1955 \\
3. & Cooperative Bank of Kenya & Large & 1965 \\
4. & I\&M Holding Ltd & Medium & 1974 \\
5. & Equity Bank & Large & 2004 \\
6. NIC Bank Ltd & Medium & 1959 \\
7. Kenya Commercial Bank Ltd & Large & 1953 \\
8. & Barclays Bank Ltd & Large & 1953 \\
9. National Bank of Kenya & Medium & 1968 \\
10. Standard Chartered & Large & 1910 \\
\hline
\end{tabular}

Source: (NSE, 2015)

\subsection{Data Collection Instruments}

The growth of commercial bank is regarded as a relatively complex process where expectations as well as real economic variables together affects the value of the firm. Among the core variables, which are seen to affect the growth of commercial banks based on the reviewed literature are the following: default loans rate, interest income level and forex transaction volume. A document analysis guide was used to collect and summaries data for the study.

\subsection{Measures of variables}

The study used pooled cross-section and time series data of individual banks' balance sheet items from the 6 commercial bank (listed in Table 3.1) for the banks, over a 4 year period from 2011 to 2014. The study utilized Secondary data since it was readily available and reflects the real position of the selected commercial banks. The level of default rate on loan was a proxy of Non-performing loans to total loans ratio (NPLR) which was the indicator of loan default rate level. While level of interest income was a proxy log interest income. Finally volume of forex transaction was a proxy of income from forex transaction to total income from non-banking activities. Firm growth which was measured by log of market shares (Ardishvili, Cardozo, Harmon \& Vadakath, 1998; Weinzimmer, Nystrom \& Freeman, 1998; Wiklund, 1998). Therefore the study measured firm growth as a proxy of total market share.

\subsection{Data Processing and Analysis}

Data was obtained from published financial reports of selected commercial banks, coded, cleaned, and entered into the computer for analysis using the SPSS and AMOS. The data was summarized in order to see emerging trends and issues around specific themes, which are dependent on the variables and objectives. The researcher compounded scores from indicators for the variables to obtain the scores respectively. According to Parveen and Leonhauser (2004) the compounding of scores from various indicators into indices is based on an integration of both qualitative and quantitative methods depending on collected data. Descriptive statistics was done to identify characteristics of demographic data of respondents while inference statistics was done for the purpose of Correlation i.e. identify the relationship between loans default rate, interest income and the effect of forex transaction volume on growth of commercial banks listed in Nairobi Securities Exchange.

\subsection{Model Specification}

To test for the effect of default loans rate, interest income and the effect of forex transaction volume on growth of commercial banks listed in Nairobi Securities Exchange, Kenya. Multiple regression analyses was conducted and the coefficient significances being examined. The multiple linear regression models that was used for the 
study is as shown below;

$$
\mathbf{y}=\beta_{0}+\beta_{1} X_{1}+\beta_{2} X_{2}+\beta_{3} X_{3}+\varepsilon
$$

Simple regression analysis with $\mathrm{Y}=$

Commercial Bank Growth (growth in dividend)

$\alpha=\quad$ Constant

$\beta 1 \ldots \beta 3=$ the slope representing degree of change in independent variable by one unit variable.

$\mathrm{X} 1=\quad$ default rate on loan

$\mathrm{X} 2=\quad$ level of interest income

$\mathrm{X} 3=\quad$ volume of forex transactions

$\varepsilon=$ error terrm

All the Significant levels was measured at 95\% confidence level with significant differences recorded at $[\mathrm{p}<0.05]$

\subsection{Preliminary Analysis}

Descriptive statistics in table 2 to 3 shows the descriptive information on interest income, growth, nonperforming loan interest rate volatility and forex transaction volumes of the six selected commercial banks listed in Nairobi stock exchange and categorized as large by the central bank.

Table 2 Descriptive Statistics

\begin{tabular}{lccccc}
\hline & $\mathrm{N}$ & Minimum & Maximum & Mean & Std. Deviation \\
\hline Loan default & 96 & 1.2 & 9.9 & 6.904 & 2.22670 \\
Interest income & 96 & 4.0 & 9.8 & 7.112 & 1.14201 \\
Forex transaction & 96 & 1.1 & 8.1 & 3.454 & 1.13102 \\
Growth & 96 & 0.44 & 4.20 & 1.6794 & 0.84334 \\
\hline
\end{tabular}

The above result on table 2 shows results of how loan default, interest income, forex transaction and growth for the all the banks as obtained from the financial statements. Loan default rate had an average of $6.09 \%$ with the standard deviation indicating high variation. Interest income had an average $7.112 \%$ with a variation close to one an indication that interest income was not vary so much from the average an indication that it will not cause so much variation on growth of commercial banks. Further forex transaction volume had average $3.454 \%$ and a variation of 1.13102 . finally the average growth of commercial banks was $1.679 \%$ which was very low while the variation was less than one an indication that all the commercial banks attributed a low growth for the five years period also reflects an upward rise over the 4 year period, with the highest being 8.14 in 2014 . In other words, the loan default rate has risen from 6.56 to $8.14 \%$ over a period of 4 years.

Table 3 Descriptive Statistics Non-Performing Loans

\begin{tabular}{llcccc}
\hline & $\mathrm{N}$ & Minimum & Maximum & Mean & Std. Deviation \\
\hline 2011 financial year & 6 & 2.35 & 6.56 & 3.745 & 1.56057 \\
2012 financial year & 6 & 1.49 & 5.43 & 3.095 & 1.60764 \\
2013 financial year & 6 & 0.70 & 5.27 & 3.050 & 1.90605 \\
2014 financial year & 6 & 1.29 & 8.14 & 4.698 & 2.60902 \\
\hline
\end{tabular}

From the findings in table 3 above shows the averages for non-performing loans for the all the banks as obtained from the financial statements reflects an upward rise over the 4 year period, with the highest being 8.14 in 2014. In other words, the loan default rate has risen from 6.56 to $8.14 \%$ over a period of 4 years. In addition, the standard deviation depict high variation in default rates in different commercial banks. The variation was high in 2014 recording a high variation of 2.609.

The findings presented in Figure 1 show that the interest rate volatility average at $14.5 \%$ close to constant in the short term than in the long term, therefore interest rate volatility can be predicted over a long period of time. There was high variability in interest rates within the last half of 2011 (June and December) before maintaining an all-time high of $20 \%$ then dropping in the last quarter of 2014 . This could owe to the monetary policy adopted by CBK following the Kenya shilling depreciation of 2011. 


\section{Figure 1Interest Rate Volatility}

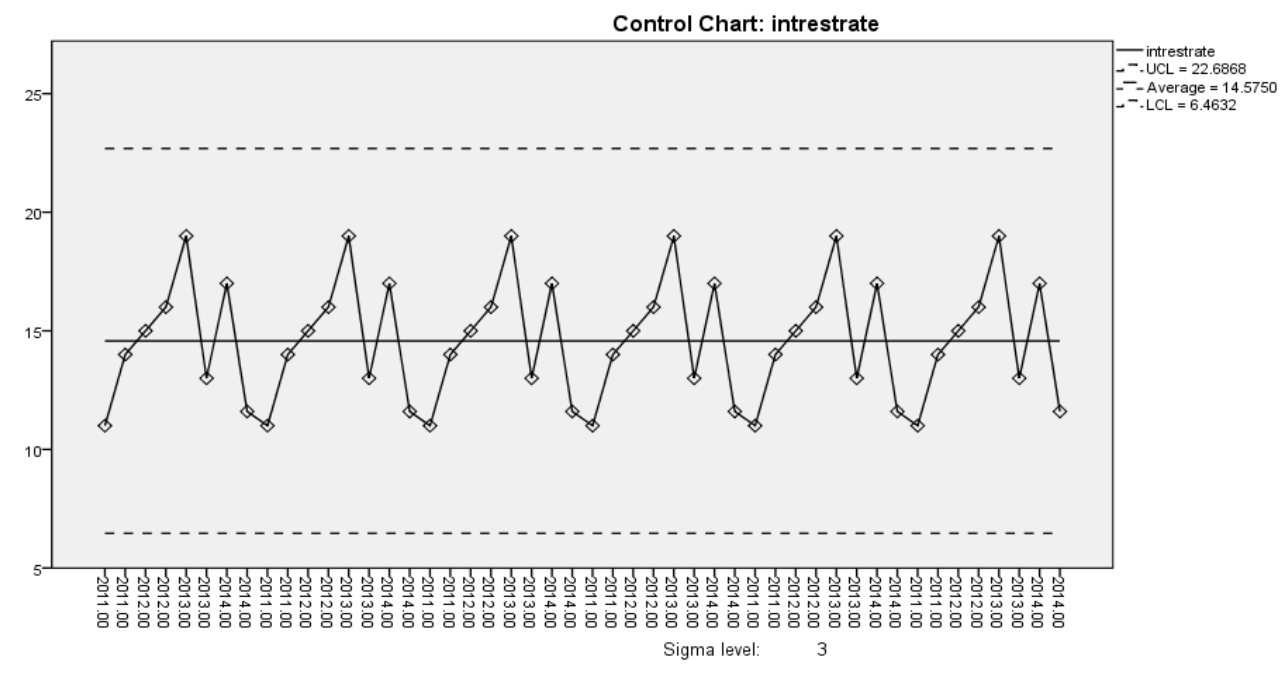

\section{Results}

Correlations results among the study variables are reported in Table 4. The levels of correlations among the variables are relatively modest, with most variables exhibiting significant correlations. Since a number of independent variables were relatively correlated, a multicollinearity analysis was conducted using Variance Inflation Factors (VIF). The results indicated that multicollinearity was not a problem since all the variables were within the recommended threshold of 10 (Hair et al., 2006).

Hypothesis 1 predicted that the more the default rate on loan in a firm, the low the growth of commercial bank. However, results on Table 5 reveals that the hypothesis hold $(\beta=-.408, p<.05)$. Hypothesis 2 suggested that the greater the level of Interest income of commercial banks the higher the growth of commercial banks. This hypothesis was supported by the results $(\beta=.307, \mathrm{p}<.05)$. Hypothesis 3 proposing that the greater the volume forex transaction, the greater the growth of commercial banks, also received support from the results $(\beta$ $=.310, \mathrm{p}<.05)$.

\section{Table 4 Correlation Test Results}

\begin{tabular}{llcccc}
\hline Control Variables & Growth & Default Rate & Interest Income & Forex Transaction \\
\hline \multirow{2}{*}{ type1 } & Growth Correlation & 1.000 & & & \\
& Default rate on loan & -.199 & 1.000 & & \\
& Interest income & $.556^{* *}$ & -.159 & 1.000 & 1.000 \\
\hline
\end{tabular}

Notes: Pearson's product moment correlation, 2 tailed test: $* \mathrm{p}<.05 ; * * \mathrm{p}<.01 ; \mathrm{N}=175$.

Table 5 Regression Test Results

\begin{tabular}{|c|c|c|c|c|c|c|c|}
\hline \multirow[t]{2}{*}{ Model } & \multicolumn{2}{|c|}{$\begin{array}{c}\text { Unstandardized } \\
\text { Coefficients }\end{array}$} & \multirow{2}{*}{$\begin{array}{c}\text { Standardized } \\
\text { Coefficients }\end{array}$} & \multirow[t]{2}{*}{$\mathbf{t}$} & \multirow[t]{2}{*}{ Sig. } & \multicolumn{2}{|c|}{ Collinearity Statistics } \\
\hline & B & Std. Error & & & & Tolerance & VIF \\
\hline (Constant) & .742 & .625 & & 1.187 & .041 & & \\
\hline default rate & -1.516 & .448 & -.408 & -3.387 & .001 & .947 & 1.056 \\
\hline Interest income & 1.822 & .732 & .307 & 2.491 & .017 & .904 & 1.106 \\
\hline forex transaction & 1.993 & .797 & .310 & 2.500 & .016 & .894 & 1.118 \\
\hline
\end{tabular}

a. Dependent Variable: Commercial Bank Growth

b. Default rate, interest income and forex transaction volume

$\mathrm{R}=.630 \mathrm{a}$

$\mathrm{R}^{2}=.396$

Adjusted $\mathrm{R}^{2}=.355$

$\mathrm{F}$ test $=141.914^{*}$

Notes: $\mathrm{N}=175 ; * \mathrm{p}<.05 ; * * \mathrm{p}<.01$.

\subsection{Discussions and conclusions}

This paper focused on three key issues: First is whether default rate on loan affects commercial bank growth, whether Interest income affects commercial bank growth and lastly whether forex transaction volume affects 
commercial bank growth. Using pooled cross-section and time series data of individual banks' balance sheet items from the 6 commercial bank, over a 4 year period from 2011 to 2014. We found support for the proposition that Interest income and forex transaction enhance growth of commercial banks. While default rate on loan affects growth of commercial banks negatively. Consistent with previous results, Loan default rate is influenced by interest rate volatility that will significantly influence growth of commercial banks (Goldstein \& Turner, 1996). In line with sentiments of Goldstein and Turner (1996) increase default rate on loans will result to increase in non-performing assets in banks and will led to increase in cost of loans charged on the borrowers which lead to loan default and hence affect bank growth negatively.

The study findings also revealed that interest income influences positively commercial banks growth. Since interest rates are highly sensitive to various factors beyond our resistor, including monetary policies and domestic and international economic and political conditions. As with any bank, changes in market interest rates will affect the interest rates charge on interest-earning assets differently than the interest rates paid on interestbearing liabilities. Finally, forex transaction volume on growth of commercial banks, it is concluded that Forex transaction volume positively affect growth of commercial banks as it is widely believed that changes in exchange rates have important implications for financial decision-making, profitability and growth of firms. At the macro level it is evidence that the creation of such currency unions results in a dramatic increase in forex exchange volume (Frankel \& Rose, 2002).

\subsection{Limitations}

The primary purpose of the study was to explore the relationship between loan default rate, interest income level and forex traction volume on growth of commercial banks listed in Nairobi securities exchange, Kenya. It is important to appreciate the study limitations. First, we cannot attribute commercial bank growth on the three studied variables (loan default rate, interest income level and forex traction volume), since there might be other factors that contribute to commercial bank growth. Secondly, the study utilized a smaller sample size and therefore future research to consider using different sectors and larger samples may provide additional insights and add to the understanding of issues explored in this study. Finally, the study focused on a single industry, although this is one way of controlling for industry effects, the results may not be representative of other sectors and so we need to interpret the results with caution. Finally it may also be fascinating to examine the establish the antecedents of interest rate volatility and effect of interest rate volatility on growth of commercial banks so as to establish the indirect effect on performance of commercial banks.

\section{Reference}

Alessandri, P. and B. Nelson (2014). Simple banking: profitability and the yield curve, Journal of Money, Credit and Banking, Vol. 47 (1), 143-175.

Ali, K., Akhtar, M. F., \& Ahmed, H. Z. (2011). Bank-Specific and Macroeconomic Indicators of ProfitabilityEmpirical Evidence from the Commercial Banks of Pakistan. International Journal of Business and Social Science, 2(6), 235-242.

Amadeo, K. (2012). US Economy. Retrieved April, 2, 2012.

Archer, M. S. (1995). Realist social theory: The morphogenetic approach. Cambridge university press.

Ardishvili, A., Cardozo, S., Harmon, S., \& Vadakath, S. (1998, May). Towards a theory of new venture growth. In Babson entrepreneurship research conference, Ghent, Belgium (pp. 21-23).

Baku, E., \& Smith, M. (1998). Loan delinquency in community lending organizations: Case studies of neighborworks organizations. Housing Policy Debate, 9(1), 151-175.

Balogun, E. D., \& Alimi, A. (1988). Loan Delinquency among Small Farmers in Developing Countries: A Case Study of the Small-Farmer Credit Programme in Lagos State of Nigeria. CBN Economic and Financial Review, 26(3).

Barajas, A., Steiner, R., \& Salazar, N. (2000). The impact of liberalization and foreign investment in Colombia's financial sector. Journal of development economics, 63(1), 157-196.

Baum, C. F., Caglayan, M., \& Ozkan, N. (2009). The second moments matter: The impact of macroeconomic uncertainty on the allocation of loanable funds. Economics Letters, 102(2), 87-89.

Baum, J. R., Locke, E. A., \& Smith, K. G. (2001). A multidimensional model of venture growth. Academy of Management Journal, 44(2): 292-303.

Beck and H. Hesse, (2009). "Why Are Interest Spreads So High in Uganda?" Journal of Development Economics, Vol. 88, No. 2, pp. 192-204. doi:10.1016/j.jdeveco.2008.07.004

Beck, T., \& Hesse, H. (2006). Bank efficiency, ownership, and market structure: why are interest spreads so high in Uganda? World Bank Policy Research Working Paper, (4027).

Bernanke and M. Gertler, (19890. "Agency Costs, Net Worth, and Business Fluctuations," American Economic Review, Vol. 79, No. 1, pp. 14-31

Brealey, R., \& Myers, S. (1995). FUNDAMENTAL SOFCORPO-RATEFINANCE7/e. 
Brealey, R.A., Myers, S.C \& Marcus, A J. (2009). Fundamentals of Corporate Finance. 6th ed McGraw -Hill

Brock and L. Rojas-Suarez, (2000). "Understanding the Behaviour of Bank Spreads in Latin America," Journal of Development Economics, Vol. 63, pp. 113-135.

Brock, P. and Franken, H. (2002). Bank Interest margins Meet Interest Rate Spreads: How good is Balance Sheet Datafor Analyzing the Cost of Financial Intermediation?

Caballero, Ricardo J., (1999). Aggregate investment, in John B. Taylor and Michael Woodford, eds., Handbook of macroeconomics, Vol 1B, Amsterdam: Elsevier.

Chatterjee, K. and Satyajit, S. (1995). Productivity and the American Business Cycle," Federal Reserve Bank of Philadelphia Business Review

Chatterjee, S. (1995). Productivity growth and the American business cycle. Business Review, (Sep), 13-22.

Chirwa and M. Mlachila, (2004). "Financial Reforms and Interest Rate Spreads in the Commercial Banking System in Malawi," IMF Staff Papers, Vol. 51, No. 1, pp. 96-122.

Chirwa, E. W. and Mlachila, M. (2004) financial reforms and Interest Rate Spreads in the Commercial Banking System in Malawi. IMF Staff Papers, 51(1), 96-122

Coad, A. (2009). The Growth of Firms: A Survey of Theories and Empirical Evidence Northampton, MA: Edward Elgar.

Crowley, J. (2007) Interest Rate Spreads in English-Speaking African Countries. IMF Working Paper, $\mathrm{WP} / 07 / 101$.

Cumby, R. E., \& Obstfeld, M. (1981). A note on exchange - rate expectations and nominal interest differentials: A test of the Fisher hypothesis. The Journal of Finance, 36(3), 697-703.

Damodaran A (2000) Value creation and enhancement: back to the future. Stern School of Business, New York Demirguc-Kunt, A. and Huizinga, H. (1998) Determinants of Commercial Bank Interest

Dash, M. K., \& Kabra, G. (2010). The determinants of non-performing assets in Indian commercial bank: An econometric study. Middle Eastern Finance and Economics, 7(2), 94-106.

Dash, M. K., \& Kabra, G. (2010). The determinants of non-performing assets in Indian commercial bank: An econometric study. Middle Eastern Finance and Economics, 7(2), 94-106.

Dell'Ariccia, G., Igan, D., Laeven, L., \& Tong, H. (2014). Policies for macro financial stability: dealing with credit booms and busts. Financial Crises: Causes, Consequences, and Policy Responses. International Monetary Fund, Washington, DC, 325-364.

Demirgüç-Kunt, A., Huizinga, H., \& Claessens, S. (1998). How does foreign entry affect the domestic banking market?. World Bank Policy Research Working Paper, (1918).

Demirgu-kunt, A. and Huizinga, H. 91997). Determinants of commercial bank interest rate the Israel experience; bank of Israel

Duarte, L. P. (2006). Ironia e humor na literatura. Editora PUC Minas.

Fernandes, R. C., Stasińska, G., Mateus, A., \& Asari, N. V. (2011). A comprehensive classification of galaxies in the Sloan Digital Sky Survey: how to tell true from fake AGN? Monthly Notices of the Royal Astronomical Society, 413(3), 1687-1699.

Fortin, M., Bravo, G., Hudon, C., Lapointe, L., Almirall, J., Dubois, M. F., \& Vanasse, A. (2006). Relationship between multimorbidity and health-related quality of life of patients in primary care. Quality of Life Research, 15(1), 83-91.

Frankel, J., \& Rose, A. (2002). An estimate of the effect of common currencies on trade and income. Quarterly Journal of economics, 437-466.

Fuller, C. C., Bargar, J. R., Davis, J. A., \& Piana, M. J. (2002). Mechanisms of uranium interactions with hydroxyapatite: Implications for groundwater remediation. Environmental Science \& Technology, 36(2), 158-165.

Gambacorta, L., \& Mistrulli, P. E. (2004). Does bank capital affect lending behavior?. Journal of Financial intermediation, 13(4), 436-457.

Giddy, I.H. (1977). Exchange Risk Whose view? Financial Management, 8, 23-33.

Goldstein, M., \& Turner, P. (1996). Banking crises in emerging economies: origins and policy options. In BIS Economic Paper 46. Bank for International Settlements, Monetary and Economic Department, Basle

Griffin, J. M., \& Stulz, R. M. (2001). International competition and exchange rate shocks: a cross-country industry analysis of stock returns. Review of Financial Studies, 14(1), 215-241.

Henry, J. D., \& Crawford, J. R. (2005). The short - form version of the Depression Anxiety Stress Scales (DASS - 21): Construct validity and normative data in a large non - clinical sample. British Journal of Clinical Psychology, 44(2), 227-239.

Henry, Ó. T., Olekalns, N., \& Suardi, S. (2005). Equity return and short-term interest rate volatility: level effects and asymmetric dynamics.

Hesse, "Financial Intermediation in the Pre-Consoli- dated Banking Sector in Nigeria," World Bank Policy Research Working Paper 4267, 2007. 
Ho, T. S., \& Saunders, A. (1981). The determinants of bank interest margins: theory and empirical evidence. Journal of Financial and Quantitative analysis, 16(04), 581-600.

Hogue M Z (2008), Flawed working capital loan policy and loan default: Evidences Bangladesh, Journal of Accounting, business and Marketing, Vol. 11, No. 2pp202-13

Iulia, I., \& Adela, S. (2010). Measuring Model for Bad Loans in Banks. The Default Probability Model. Annals of the University of Oradea, Economic Science Series, 19(2).

Jensen, M. C., \& Meckling, W. H. (1976). Theory of the firm: Managerial behavior, agency costs and ownership structure. Journal of financial economics, 3(4), 305-360.

Jiménez, G., \& Saurina, J. (2005). Credit cycles, credit risk and prudential regulation (No. 0531). Banco de España.

Kim, J. B., Li, Y., \& Zhang, L. (2011). Corporate tax avoidance and stock price crash risk: Firm-level analysis. Journal of Financial Economics, 100(3), 639-662.

Kipchirchir, I. C. (2011). The versatility of the negative binomial distribution in describing dispersion.

Leedy, P. N., \& Ormrod, J. E. (2005). Practical research. Publisher not identified.

Levine, R., \& Zervos, S. (1998). Stock markets, banks, and economic growth. American economic review, $537-$ 558.

Madura, J. (2010). International Financial Management, 10th Edition, South-Western College Publishing.

Memmel, C. (2008): Which interest rate scenario is the worst one for a bank? Evidence from a tracking bank approach for German savings and cooperative banks, International Journal of Banking, Accounting and Finance, Vol. 1(1), 85-104.

Memmel, C. (2011): Banks' exposure to interest rate risk, their earnings from term transformation, and the dynamics of the term structure, Journal of Banking \& Finance, Vol. 35, 282-289.

Memmel, C. (2014): Banks' interest rate risk: the net interest income perspective versus the market value perspective, Quantitative Finance, Vol. 14(6), 1059-1068.

Ndung'u and R. W. Ngugi, "Banking Sector Interest Rate Spreads in Kenya," Kenya Institute for Public Policy Research and Analysis (KIPPRA), Discussion Paper No. 5, 2000.

Nelson, R. R., \& Winter, S. G. (1982). The Schumpeterian trade off revisited. The American Economic Review, 72(1), 114-132.

Ngetich, J.C., \& Wanjau, K. (2011). The Effects of Interest Rate Spread on the Level of Non-Performing Assets. Case of Commercial Banks in Kenya.

Ngugi, R. W., Amanja, D., \& Maana, I. (2010). The Capital Market and Economic Growth in Kenya.

Olweny, T., \& Shipho, T. M. (2011). Effects of banking sectoral factors on the profitability of commercial banks in Kenya. Economics and Finance Review, 1(5), 1-30.

Omagwa, J. (2005). Foreign exchange risk management practices by foreign owned commercial banks in Kenya-. Unpublished MBA research project, university of Nairobi.

Orodho, J. A. (2004). Techniques of writing research proposals and reports in education and social sciences. Nairobi: Masola Publishers.

Parveen, S. Leonhauser. (2004). Empowerment of Rural Women in Bangladesh: A Household Level Analysis, 5-7.

Rajan, R. G., \& Zingales, L. (1998). Which capitalism? Lessons from the East Asian crisis. Journal of Applied Corporate Finance, 11(3), 40-48.

Randall, "Interest Rate Spreads in the Eastern Carib-bean," IMF Working Paper, WP/98/59.

Samuel and L. Valderrama, "The Monetary Policy Regime and Banking Spreads in Barbados," IMF Working Paper, WP/06/211, 2006.

Saunders and L. Schumacher, "The Determinants of Bank Interest Rate Margins: An International Study," Journal of International Money and Finance, Vol. 19, No. 6, pp. 813-832. doi:10.1016/S02615606(00)00033-4.

Saunders, M., Lewis, P., \& Thornhill, A. (2009). Research methods for business students. 5th edition. Harlow: Financial Times Prentice Hall.

Sayedi, S., (2013). Bank specific, industrial specific and macroeconomic determinants of banks profitability in Nigeria. Journal of Finance

Sensarma, R. and Jayadev, M. (2009). Are bank stocks sensitive to risk management? Journal of Risk Finance, the, 10 (1), pp. 7--22.

Shalit, S.S. \& Sankar, U. (1977). The Measurement of Firm Size. Review of Economics and Statistics, 59(3), 290-298

Shrestha, M. (2005). Financial Liberalization in Nepal, PHD thesis, School of Economics and Information System, University of Wollongong.

Sutton, P., \& Doidge, C. (2003). Helicobacter pylori vaccines spiral into the new millennium. Digestive and liver disease, 35(10), 675-687.

Tennant and A. Folawewo, "Macroeconomic and Market Determinants of Banking Sector Interest Rate Spread: 
Empirical Evidence from Low and Middle In-come Countries," Department of Economics, University of West Indies, Mona, Mimeo.

Ubindi, B. S. (2006). A survey of foreign exchange risk management practices by forex bureaus in Kenya (Doctoral dissertation).

Valverde, R. L. del Pasto and F. R. Fernandez, "Banks, Financial Innovations and Regional Growth," 2004. www.ugr.es/ franrod/ingrowth04.pdf

Von Pischke, J. D., \& Adams, D. W. (1980). Fungibility and the design and evaluation of agricultural credit projects. American Journal of Agricultural Economics, 62(4), 719-726.

Weinzimmer, L. G., Nystrom, P. C., \& Freeman, S. J. (1998). Measuring organizational growth: Issues, consequences and guidelines. Journal of management, 24(2), 235-262.

Williamson, J. (1990). What Washington means by policy reform. Latin American adjustment: How much has happened, 7, 7-20.

Wong, "On the Determinants of Bank Interest Mar-gins under Credit and Interest Rate Risks," Journal of Banking and Finance, Vol. 21, No. 2, 1997, pp. 251-271. doi:10.1016/S0378-4266(96)00037-4. 